\title{
Turning the Commission's Farm to Fork Strategy into a far-reaching reform of EU agriculture
}

\author{
Peter Stevenson \\ Chief Policy Advisor \\ Compassion in World Farming, United Kingdom
}

Cita recomendada. STEVENSON, P., Turning the Commission's Farm to Fork Strategy into a far-reaching reform of EU agriculture, dA. Derecho Animal (Forum of Animal Law Studies) 11/4 (2020). - DOI https://doi.org/10.5565/rev/da.521

\begin{abstract}
Despite the EU's claim to lead the world on farm animal welfare, much of the EU livestock sector is industrial with poor welfare standards. Moreover, the crowded, stressful conditions of industrial livestock production contribute to the emergence, spread and amplification of pathogens, some of which are zoonotic. Industrial production is dependent on the routine use of antimicrobials to prevent the bacterial diseases that are inevitable when animals are kept in poor conditions. This leads to the emergence of antimicrobial resistance in animals which can in turn be transferred to people, so undermining the efficacy of the antimicrobials that are so important in human medicine. In order to reduce disease risk and save our antibiotics, we need to move to 'health-oriented systems' for rearing animals in which good health is inherent in the farming methods rather than being propped up by routine use of antimicrobials. Industrial livestock production is also dependent on feeding human-edible cereals to animals who convert them very inefficiently into meat and milk. 57\% of EU cereals are used to feed farm animals. Industrial production's huge demand for cereals has fuelled intensive crop production which with its monocultures and agrochemicals has led to soil degradation, overuse and pollution of ground- and surface-water, and biodiversity loss including sharp declines in pollinators and farmland birds. We need to transform the role of animals; they only make an efficient contribution to food security when they are converting materials we cannot consume - e.g. grass, crop residues, by-products and unavoidable food waste - into food we can eat. We need to move to regenerative agriculture such as agroecology which can minimise the use of pesticides and fertilisers, while in some cases, enhancing productivity by supporting and harnessing natural processes.
\end{abstract}

Key words: animals; livestock; animal welfare; pathogens; agroecology; antimicrobials.

Resumen - Convertir la estrategia de la Comisión de la granja a la mesa en una reforma de gran alcance de la agricultura de la UE

A pesar de la afirmación de la UE de ser líder mundial en bienestar de los animales de granja, gran parte del sector ganadero de la UE es industrial y tiene unos estándares de bienestar deficientes. Además, las condiciones estresantes y hacinadas de la producción ganadera industrial contribuyen a la aparición, propagación y amplificación de patógenos, algunos de los cuales son zoonóticos. La producción industrial depende del uso rutinario de antimicrobianos para prevenir las enfermedades bacterianas que son inevitables cuando los animales se mantienen en malas condiciones. Esto conduce a la aparición de resistencias a los antimicrobianos en los animales que, a su vez, pueden transferirse a las personas, lo que socava la eficacia de 
los antimicrobianos que son tan importantes en la medicina humana. Para reducir el riesgo de enfermedades y conservar nuestros antibióticos, debemos pasar a "sistemas orientados a la salud" para la cría de animales en los que la buena salud es inherente en los métodos de cría en lugar de estar respaldada por el uso rutinario de antimicrobianos. La producción ganadera industrial también depende de la alimentación de animales con cereales comestibles para humanos, que los convierten de manera muy ineficaz en carne y leche. El 57\% de los cereales de la UE se utilizan para alimentar a los animales de granja. La enorme demanda de cereales de la producción industrial ha impulsado la producción intensiva de cultivos que, con sus monocultivos y agroquímicos, ha provocado la degradación del suelo, el uso excesivo y la contaminación de las aguas subterráneas y superficiales, y la pérdida de biodiversidad, incluida una fuerte disminución de los polinizadores y las aves de las tierras de cultivo. Necesitamos transformar el papel de los animales; solo hacen una contribución eficiente a la seguridad alimentaria cuando están convirtiendo materiales que no podemos consumir - por ejemplo, pasto, residuos de cultivos, subproductos y desperdicio inevitable de alimentos - en alimentos que podemos comer. Necesitamos pasar a la agricultura regenerativa, como la agroecología, que puede minimizar el uso de pesticidas y fertilizantes y, en algunos casos, mejorar la productividad al respaldar y aprovechar los procesos naturales.

Palabras clave: animales; ganado; bienestar de los animales; patógenos; agroecología; antimicrobianos.

\section{Animal welfare}

The Commission's Farm to Fork Strategy promises to revise EU legislation on farm animal welfare. This is welcome, although they may not realise how much needs to be done to bring EU animal welfare up to an acceptable level. Major animal welfare problems are woven throughout much of the EU livestock sector. This is due to poor enforcement, undemanding legislation e.g. the Broilers Directive, ${ }^{1}$ and the lack of speciesspecific Directives for several farmed species e.g. dairy cows, beef cattle, rabbits, turkeys, ducks and geese.

Despite the ban on sow stalls, most EU sows are confined in stalls for the first 28 days of their pregnancy. ${ }^{2}$ As sows on average produce 2.25 litters per year, this means that most are confined in stalls so narrow that they cannot even turn round for around nine weeks of the year. This is only half the problem. Nearly all EU sows are placed in farrowing crates a few days before giving birth; they are kept there while giving birth and until the piglets are weaned at three to four weeks of age. This means that they spend a second batch of nine weeks of the year in stalls so narrow that they cannot even turn round. Farmers say they need to use farrowing crates to prevent the sows from crushing their piglets but alternative free farrowing pens have been developed which give the sows a reasonable amount of space and the best of these can keep piglet mortality as low as, or lower than, in farrowing crates. ${ }^{3}{ }^{4}$ The EU must now phase out by law the use of farrowing crates and repeal the derogation that allows sow stalls to be used for the first 28 days of the pregnancy.

The role of sows on the farm is to produce large numbers of piglets. I now want to look at what happens to those piglets as they are raised for pork, bacon and ham. Nearly all fattening pigs in the EU are farmed intensively, being kept in barren, overcrowded conditions. In natural conditions pigs will spend $75 \%$ of their daylight hours in activity: rooting, foraging and exploring. ${ }^{5}$ None of this is possible in industrial farms. So they turn to the only other thing in their pens: the tails of other pigs. Bored and frustrated, they begin to chew - and then bite - these tails. To prevent this, farmers dock - cut off - part of the tail. But for many years scientific research has shown that the right way to prevent tail biting is not to dock the tails but to keep the pigs in good conditions, above all to give them enrichment materials such as straw. ${ }^{6}$ Accordingly, many years

\footnotetext{
${ }^{1}$ Council Directive 2007/43/EC laying down minimum rules for the protection of chickens kept for meat production

${ }^{2}$ Article 3.4 of Council Directive 2008/120/EC laying down minimum rules for the protection of pigs requires sows and gilts to be kept in groups during a period starting from four weeks after insemination

${ }^{3}$ BAXTER, EM, LAWRENCE, AB, EDWARDS, SA. Alternative farrowing accommodation: welfare and economic aspects of existing farrowing and lactation systems for pigs. Animal 6.01 (2012) 96-117 doi: 10.1017/S1751731111001224

${ }^{4}$ WEBER, R, KEIL, N, FEHR, M, HORAT, R. Piglet mortality on farms using farrowing systems with or without crates. Animal Welfare 16 (South Mimms 2007) 277-279.

${ }^{5}$ STOLBA, A, WOODGUSH, DGM. The behaviour of pigs in a semi-natural environment Animal Protection. 48 (Cambridge 1989) 419-425. RUSSELL, WMS, BURCH, RL, The Principles of Humane Experimental Technique (London 1959) 112.

${ }^{6}$ Scientific Opinion of the Panel on Animal Health and Welfare on a request from Commission on the risks associated with tail biting 
ago, following the science, EU law banned routine tail docking. ${ }^{7}$ The law provides that before farmers may tail dock, they must first try to prevent tail biting by improving the conditions on the farm. If having done this, they still have a tail biting problem, they can dock but only the next batch of pigs. They must then return to trying to prevent tail biting by improving the pigs' conditions. The ban on routine tail docking has been in force for 26 years. Yet over $98 \%$ of EU pigs are still routinely tail docked. ${ }^{8}$ This is a staggering lack of respect for the law by the pig sector. And an appalling failure to enforce the law by the Member States. The European Commission must now take urgent steps to at long last secure enforcement of this law.

Council Directive 1999/74/EC prohibited barren battery cages for laying hens from 1 January 2012. However, around $50 \%$ of EU laying hens are kept in enriched cages ${ }^{9}$ which are only a little better for welfare than the prohibited barren cage. Hens' ability to move and exercise is seriously restricted in enriched cages. The European Food Safety Authority (EFSA) has concluded that due to the limited space in enriched cages "the behavioural repertoire is still restricted compared with birds in non-cage systems". ${ }^{10}$ Austria and Luxembourg have already banned enriched cages and Germany's ban comes into force in 2025. France has prohibited the installation of any new enriched cages; this prohibition entered into force on 1 November 2018. In November 2020 Czechia banned the use of enriched cages from 2027. The EU as a whole must now ban enriched cages.

The EU has detailed Directives on the welfare of pigs, calves, laying hens and broilers. However as indicated earlier, for many species such as dairy cows and rabbits, there are no detailed welfare protections. These species are covered only by Directive 98/58/EC - often known as the General Farm Animals Directive. ${ }^{11}$ This Directive's language is very broad which makes enforcement difficult. But though broad, the language is strong. Article 3 provides that farmers must take "all reasonable steps to ensure the welfare of animals under their care and to ensure that those animals are not caused any unnecessary pain, suffering or injury". So, how can we use this language to protect animals? The European Commission has said that one must look at EFSA's scientific reports and opinions as these will identify what are the main welfare problems affecting a particular species and what are the "all reasonable steps" that must be taken to address these problems. $^{12}$

My colleague Dr Elena Nalon from Eurogroup for Animals and I have published a detailed paper showing for dairy cows what are the key problems and what are the "all reasonable steps" that must be taken to address them. ${ }^{13}$ I hope other lawyers will undertake similar work for other species that are not covered by a detailed species-specific Directive. It is important that lawyers take forward the task of detailing how the General Farm Animals Directive applies to each species.

Each year millions of farm animals are transported huge distances across the EU. Packed into overcrowded trucks, they become increasingly exhausted, dehydrated and stressed as the long journeys wear on. Enforcement of Council Regulation 1/2005/EC on the protection of animals during transport is poor. ${ }^{14}$ The same breaches of the Transport Regulation can be found today as were commonplace thirty years ago. Little has improved. The main breaches include overcrowding, lack of sufficient headroom, transport of unfit animals, and failure to give the animals rest, feed and water as required by the Regulation during long journeys. In addition to the journeys within the EU, Eurostat data show that the EU exports around three million cattle and sheep a year to the Middle East, North Africa and Turkey. The journeys to Turkey are mainly by road. Those to the Middle East and North Africa entail a road journey to a seaport followed by a long sea journey.

in pigs and possible means to reduce the need for tail docking considering the different housing and husbandry systems. The EFSA Journal 611 (2007) 1-13

${ }^{7}$ Council Directive 2008/120/EC laying down minimum rules for the protection of pigs, Annex I, Chapter I, point 8 . The ban on routine tail docking was initially enacted in Council Directive 91/630/EEC, point 4 of Chapter II of the Annex.. The Annex to Directive 91/630 was replaced by Commission Directive 2001/93/EC. Point 8 of Chapter I. This has now been codified in Council Directive 2008/120/EC.

${ }^{8}$ European Commission, 14 November 2019. Outcome of Commission actions to reduce tail biting and prevent routine tail docking of pigs.

https://ec.europa.eu/info/food-farming-fisheries/key-policies/committees-and-advisory-councils/civil-dialogue-groups/animalproducts_en\#y2019

${ }_{9}$ European Commission, 19 September 2019. EU Market Situation for Eggs: Committee for the Common Organisation of the Agricultural Markets

${ }_{10}$ European Food Safety Authority: Panel on Animal and Welfare. Scientific opinion on welfare aspects of various systems for keeping laying hens. Annex to The EFSA Journal 197 (2005) 1-23

${ }^{11}$ Council Directive 98/58/EC concerning the protection of animals kept for farming purposes

${ }^{12}$ Letter dated 16 December 2013 from Commissioner Borg (reference A (2013) 03696985) in response to an open letter dated 23 October 2013 presented by petitioners from the "Supporting Better Dairy" campaign

${ }^{13}$ NALON, E, STEVENSON, P. Protection of Dairy Cattle in the EU: State of play and directions for policymaking from a legal and animal advocacy perspective. Animals 9, (2019) 1066; doi:10.3390/ani9121066

${ }^{14}$ European Parliament resolution of 14 February 2019 on the implementation of Council Regulation (EC) No 1/2005 on the protection of animals during transport within and outside the EU (2018/2110(INI)) 
The Court of Justice of the EU has ruled in the Zuchtvieh case (C-424/13) that in the case of live exports, the Regulation on the protection of animals during transport continues to apply even after the animals have left the EU; it applies all the way through to the destination in the non-EU country. However, this Court of Justice ruling is regularly ignored by transporters, most Member States and the European Commission. ${ }^{15} 16$ Indeed, a recent overview report published by the European Commission on live exports by road states that most transporters do not meet EU rules on the protection of animals during transport after leaving the EU. ${ }^{17}$

The Commission's overview report on live exports by sea shows that the authorities permit animals to be loaded onto the ship even when pre-loading inspections of the ship reveal deficiencies. ${ }^{18}$ Regulation 1/2005 requires the authority at the sea port to inspect the animals before loading to ensure they are fit to continue their journey. The report shows that "checking the fitness of the animals is generally a weak point" and is not being properly carried out. The report shows that neither the exporters nor the Member State authorities are giving any proper consideration to the animals' welfare during the sea journeys themselves. The report states "neither the Member States nor the Commission have information or statistics on the health and welfare state of the animals during sea journeys". Shockingly, the report reveals that it is unclear who is legally responsible for, and can be held to account for, the wellbeing of the animals during the sea part of the journey. It adds "There is currently no routine feedback from third countries, transporters or ships' Masters on the condition of animals during the sea journey nor on the conditions in which they arrive at destination." This is a scandal. The EU should urgently prohibit the live export of animals from the EU.

There are many slaughter problems in the EU. I want to look at two of them. The publication Poultry World estimates that $80 \%$ of chickens in the EU are stunned in the electrical waterbath. ${ }^{19}$ The Scientific Opinion published by EFSA in October 2019 highlights the serious welfare problems that are inherent or common in the stunning of poultry in the electrical waterbath. ${ }^{20}$ The birds are turned upside down and hung from metal shackles. These are on a moving line. This takes them to an electrified waterbath through which their heads are dragged; this is designed to stun them. The moving line then takes them to automatic neck cutters. Electrical waterbath stunning involves inverting the birds and then forcing their legs into tight metal shackles. The EFSA Opinion concludes: "Hanging upside down is a physiologically abnormal posture for poultry; inversion, and shackling are practices that cause pain and fear in conscious birds."

Council Regulation 1099/2009 on the protection of animals at the time of killing permits the use of frequencies of up to 1500 hertz $(\mathrm{Hz})$. However, the EFSA Opinion concludes that frequencies over $600 \mathrm{~Hz}$ cannot reliably produce an effective stun; this applies to both broilers and turkeys. EFSA stresses that "Inevitably, ineffective electrical stunning parameters would have serious welfare consequences". In its conclusions EFSA states that frequencies should not exceed $600 \mathrm{~Hz}$ for broilers or turkeys. Some birds receive too little current to be effectively stunned. The EFSA Opinion states: "With multiple birds waterbath, each bird may not receive the same current and, for some birds, it might be not sufficient to induce unconsciousness. This is because the method is not capable of coping with biological variations among birds". EFSA concludes: "some birds don't receive sufficient current to become unconscious". EFSA stresses that "ineffective stunning will lead to persistence of consciousness during neck cutting, or recovery of consciousness during bleeding. Both these situations are very painful and fearful for animals". In 2004 EFSA said that, given these problems, this stunning method must be replaced as soon as possible. ${ }^{21}$ But now, 16 years later, around six billion chickens and turkeys a year are stunned in the electrical waterbath in the EU. We have often written to the European Commission urging them to bring this stunning method to an end and, in the meantime, to strengthen the requirements in the legislation, but always the Commission refuses to act.

Many pigs in the EU are stunned with high concentrations of carbon dioxide $\left(\mathrm{CO}_{2}\right)$ gas even though for many years scientific research has shown that this method leads to severe respiratory distress and hyperventilation..$^{22}{ }^{23}$ The pigs can be seen struggling to escape from the chamber. In June 2020 a new EFSA scientific opinion stressed that "Exposure to $\mathrm{CO}_{2}$ at high concentrations is considered a serious welfare

\footnotetext{
${ }^{15}$ European Commission, 2020. Overview report: welfare of animals transported by sea. DG (SANTE) 2019-6835

${ }^{16}$ European Commission, 2020. Overview report: welfare of animals exported by road. DG (SANTE) 2019-6834

${ }^{17}$ Ibid

${ }^{18}$ European Commission, 2020. Overview report: welfare of animals transported by sea. DG (SANTE) 2019-6835

${ }^{19}$ Poultry World, 7 January 2019. Diversity, not uniformity in waterbath stunning.

https://www.poultryworld.net/Health/Articles/2019/1/Diversity-not-uniformity-in-waterbath-stunning-378064E/

${ }^{20}$ EFSA Panel on Animal Health and Animal Welfare. Scientific opinion on Slaughter of

animals: poultry. EFSA Journal, 17/11 (2019) 5849 https://doi.org/10.2903/j.efsa.2019.5849

${ }^{21}$ The EFSA Journal, 45 (2004) 1-29, Welfare aspects of the main systems of stunning and killing the main commercial species of animals

${ }^{22}$ Ibid

${ }^{23}$ RAJ, ABM, GREGORY, NG. Welfare implications of the gas stunning of pigs: 2. Stress of induction of anaesthesia. Animal Welfare, 5 (1996) 71-78
}

180 Derecho Animal. Forum of Animal Law Studies, vol. 11/4 
concern by the Panel, because it is highly aversive and causes pain, fear and respiratory distress". ${ }^{24}$ It stated "there are no preventive or corrective measures to the pain, fear and respiratory distress caused by the exposure to high $\mathrm{CO}_{2}$ concentrations as this is inherent to the stunning method." EFSA recommended that "exposure to $\mathrm{CO} 2$ at high concentration should be replaced by exposure to other gas mixtures that are less aversive". Again, often we have asked the European Commission to replace this inhumane method but they refuse to take any effective action.

\section{Environmental considerations}

The Farm to Fork Strategy recognises the environmental degradation being caused by intensive agriculture and it promises to reduce the use of pesticides by $50 \%$ and the use of fertilisers by at least $20 \%$ by 2030 and to restore biodiversity. This is welcome but the Commission's Strategy fails to recognise the link between industrial livestock production and environmental problems.

Commission data show that $57 \%$ of EU cereals are used to feed animals. ${ }^{25}$ This undermines food security as animals convert these cereals very inefficiently into meat and milk. For every 100 calories of human-edible cereals fed to animals, just 17-30 calories enter the human food chain as meat or milk. ${ }^{26}{ }^{27}$ For every 100 grams of protein in human-edible cereals fed to animals, just 43 grams of protein enter the human food chain as meat or milk. ${ }^{28}$ The Commission's Joint Research Centre has said that the "use of highly productive croplands to produce animal feedstuffs ... represents a net drain on the world's potential food supply". ${ }^{29}$ It adds "even efficient use of productive cropland for animal feed is a potential reduction of the global food supply". This huge demand by industrial livestock for cereals as feed has played a part in fuelling the intensification of crop production. This, with its monocultures and agro-chemicals, has led to soil degradation, ${ }^{30}$ biodiversity loss, ${ }^{31}$ overuse and pollution of ground- and surface-water, ${ }^{32}$ and air pollution ${ }^{33}$.

The fertilisers used to grow animal feed crops contain high levels of nitrogen. The crops only absorb $30-60 \%$ of this nitrogen; $40-70 \%$ of this nitrogen is lost to water or the atmosphere. ${ }^{34}$ The concentrate feed given to industrial livestock also contains high levels of nitrogen. However, pigs and poultry absorb less than half of this nitrogen; most is excreted in their manure. The nitrogen that is not absorbed by the crops or the animals runs off or leaches to pollute rivers, lakes, groundwater, and marine ecosystems. A 2019 World Bank report states: "Frequently more than half of nitrogen fertilizer leaches into water or the air. In water, it may result in hypoxia and dead zones - problems that arise from a lack of dissolved oxygen in water that can take centuries to recover". ${ }^{35}$

Intensive farmed animals eat not just cereals but soy. The EU imports 36 million tonnes of soy per year mainly from South America. ${ }^{36} 95 \%$ is used as animal feed, mostly in the intensive pig and poultry sectors. ${ }^{37}$ Soy production leads to expansion of farmland into forests and savannahs resulting in loss of biodiversity and the release of huge quantities of stored carbon into the atmosphere.

\section{The need to move to new ways of farming}

\footnotetext{
${ }^{24}$ EFSA AHAW Panel (EFSA Panel on Animal Health and Welfare). Scientific Opinion on the welfare of pigs at slaughter. EFSA Journal, 18/6 (2020) 6148. https://doi.org/10.2903/j.efsa.2020.6148

${ }^{25}$ EU market: cereals supply \& demand http://ec.europa.eu/agriculture/cereals/balance-sheets/cereals/overview_en.pdf

${ }^{26}$ LUNDQVIST, J, DE FRAITURE, C, MOLDEN, D. Saving Water: From Field to Fork - Curbing Losses and Wastage in the Food Chain (Stockholm, 2008). SIWI Policy Brief.

${ }^{27}$ NELLEMANN, C, MACDEVETTE, M, MANDERS, EICKHOUT, B, SVIHUS, B, PRINS, AG, KALTENBORN, B (Eds). The environmental food crisis - The environment's role in averting future food crises. A UNEP rapid response assessment. United Nations Environment Programme, GRID-Arendal (2009), www.unep.org/pdf/foodcrisis_lores.pdf

${ }^{28}$ BERNERS-LEE M, WATSON, R, KENNELLY, C, HEWITT, CN. Current global food production is sufficient to meet human nutritional needs in 2050 provided there is radical societal adaptation. Elem Sci Anth, 6 (2018) 52

${ }^{29}$ European Commission Joint Research Centre, Atlas of Desertification (2018)

${ }^{30}$ EDMONDSON, JL, DAVIES, ZG, GASTON, KJ. Urban cultivation in allotments maintains soil qualities adversely affected by conventional agriculture. Journal of Applied Ecology, 51 (2014) 880-889

${ }^{31}$ World Health Organization and Secretariat of the Convention on Biological Diversity. Connecting global priorities: biodiversity and human health (2015)

32 MEKONNEN, M, HOEKSTRA, A. A global assessment of the water footprint of farm animal products. Ecosystems (2012) DOI: 10.1007/s10021-011-9517-8

${ }^{33}$ LELIEVELD J, EVANS, JS, GIANNADAKI, D, POZZER, A. The contribution of outdoor air pollution sources to premature mortality on a global scale. Nature, 525 (2015)

34 SUTTON MA, HOWARD, CM, ERISMAN, JW, BILLEN, G, BLEEKER, A, GRENNFELT, P, VAN GRINSVEN, H, GRIZZETTI, B (Eds.) The European Nitrogen Assessment (Cambridge 2011).

${ }^{35}$ DAMANIA, R, DESBUREAUX, S, RODELLA, A-S, RUSS, J, ZAVERI, E. Quality Unknown : The Invisible Water Crisis (Washington, DC 2019) World Bank. https://openknowledge.worldbank.org/handle/10986/32245

${ }^{36}$ Commission Staff Working Document. Genetically modified commodities in the EU. Brussels, 8.3.2016 SWD (2016) 61 final

${ }^{37}$ Commission Presentation "Development of plant proteins in the European Union" (9 October 2018).
} 
If we wish to address these problems, we need to move to new ways of farming. First, we need to redefine the role of livestock. Animals are only efficient when they are converting materials we cannot consume into food that we can eat. ${ }^{38}{ }^{39}$ Efficient ways of feeding animals include: raising them extensively on pasture or other grassland, feeding them on crop residues or by-products such as brewers' grains or citrus pulp, or unavoidable food waste such as left-over bakery products or cull fruit and vegetables.

Second, we need to move to regenerative forms of agriculture such as agroecology. This can minimise the use of pesticides and fertilisers, while at the same time in some cases enhancing productivity and it achieves this by supporting - and harnessing - natural processes ${ }^{40}$ It can build soil quality by the use of animal manure, composts, cover crops and rotations that include legumes which can 'fix' atmospheric nitrogen into the soil. ${ }^{41}$

Agroecology can minimise pests and plant diseases by Integrated Pest Management. ${ }^{42}$ For example, by allowing the natural enemies of pests to thrive (while pesticides tend to kill them) and by developing healthy soils which can promote strong healthy plants which are better able to resist disease and pest attacks. Moreover, the use of rotations can impede the build-up of pathogens and pests that often occurs when the same plants are continuously cropped. Regenerative agriculture can also restore biodiversity enabling farmland birds, pollinators, butterflies and wildlife to thrive once again. A detailed French study reports that agroecology could provide a healthy diet for Europeans by 2050 while reducing greenhouse gas emissions and restoring soils and biodiversity. ${ }^{43}$

Third, we need to restore the link between animals and the land through rotational integrated croplivestock systems. One typical system would involve Year One: Wheat, Year Two: Barley, Year Three: Oats, Years Four to Seven: Grazing. In such a system the animals are fed on grass, crop residues and root crops grown on the farm. During the grazing part of the rotation soil quality is being built through animal manure, the ability of the roots of grasses to collect minerals from deep in the soil and the inclusion in the grass of protein-rich legumes such as clover. All this means that the arable part of the rotation can be undertaken without the use of artificial fertilisers.

So far I have been looking at changes needed in production. However, consumption also needs to be considered. The Farm to Fork Strategy states that nearly $70 \%$ of the greenhouse gas (GHG) emissions produced by EU agriculture come from livestock. A RISE (Rural Investment Support for Europe) Foundation study in 2018 said that livestock-related GHG emissions must be reduced by $74 \%$ by 2050 for the livestock sector to play its part in meeting the EU's then emissions reduction targets. ${ }^{44}$ Since then the EU has strengthened its ambitions and now aims to achieve net-zero emissions by $2050 .{ }^{45}$

Many studies are showing that without a substantial reduction in the consumption of meat and dairy products it will be very difficult to meet the EU and Paris climate targets. ${ }^{46} 47$

Reducing the consumption of meat and dairy would also lead to many other benefits. It would lead to a big reduction in the incidence of heart disease ${ }^{48}$ and a decrease in the use and pollution of water ${ }^{49}$ and in the use of arable land. ${ }^{50}$ There would be substantial reductions in GHG emissions and in emissions of nitrogen

\footnotetext{
${ }^{38}$ SCHADER, C, MULLER, A, SCIALABBA, NE-H, HECHT, J, ISENSEE, A, ERB, K-H, SMITH, P, HARINDER, PSM, KLOCK, P, LEIBER, F, SCHWEGLER, P, STOLZE, M, NIGGLE, U. Impacts of feeding less food-competing feedstuffs to livestock on global food system sustainability. J. R. Soc. Interface 12 (2015) 20150891. http://dx.doi.org/10.1098/rsif.2015.0891

${ }^{39}$ BAJŽELJ, B, RICHARDS, KS, ALLWOOD, JM, SMITH, P, DENNIS, JS, CURMI, E, GILLIGAN, CA. Importance of fooddemand management for climate mitigation. Nature Climate Change (2014) http://www.nature.com/doifinder/10.1038/nclimate2353 ${ }^{40}$ POUX, X, AUBERT, P-M. An agroecological Europe in 2050: multifunctional agriculture for healthy eating (2018) https://www.iddri.org/sites/default/files/PDF/Publications/Catalogue\%20Iddri/Etude/201809-ST0918EN-tyfa.pdf

${ }^{41}$ Food and Agriculture Organisation of the United Nations. Agroecology to reverse soil degradation and achieve food security (Rome 2015) http://www.fao.org/3/a-i4803e.pdf

42 BRZOZOWSKI, L, MAZOUREK, M. A Sustainable Agricultural Future Relies on the Transition to Organic Agroecological Pest Management. Sustainability 10 (2018) 2023 https://www.mdpi.com/2071-1050/10/6/2023

${ }^{43}$ POUX, X, AUBERT, P-M. An agroecological Europe in 2050. multifunctional agriculture for healthy eating (2018) https:/www.iddri.org/sites/default/files/PDF/Publications/Catalogue\%20Iddri/Etude/201809-ST0918EN-tyfa.pdf

${ }^{44}$ BUCKWELL, A, NADEU, E. What is the Safe Operating Space for EU Livestock? RISE Foundation (Brussels 2018)

${ }^{45}$ European Commission. The European Green Deal: COM (2019) 640 final (Brussels)

${ }^{46}$ BAJŽELJ, B, RICHARDS, KS, ALLWOOD, JM, SMITH, P, DENNIS, JS, CURMI, E, GILLIGAN, CA. Importance of fooddemand management for climate mitigation. Nature Climate Change (2014) http://www.nature.com/doifinder/10.1038/nclimate2353

${ }^{47}$ BAILEY, R, FROGGATT, A, WELLESLEY, L. Livestock - Climate Change's Forgotten Sector (London 2014). Chatham House. https://www.chathamhouse.org/publication/livestock-climate-change-forgotten-sector-global-public-opinion-meat-and-dairy

${ }^{48}$ FRIEL, S, DANGOUR, AD, GARNETT, T, LOCK, K, CHALABI, Z, ROBERTS, I, BUTLER, A, BUTLER, CD, WAAGE, J, MCMICHAEL, AJ, HAINES A. Health and Climate Change 4: Public health benefits of strategies to reduce greenhouse-gas emissions: food and agriculture (2009)

49 VANHAM D et al. The water footprint of the EU for different diets. Ecological indicators 32 (2013) 1-8 http://waterfootprint.org/media/downloads/Vanham-et-al-2013 2.pdf

50 WESTHOEK, H, LESSCHEN, JP, ROOD, T, WAGNER, S, DE MARCO, A, MURPHY-BOKERN, D, LEIP, A, VAN 182 Derecho Animal. Forum of Animal Law Studies, vol. 11/4
} 
and a very large decrease in the import of soy for animal feed. ${ }^{51}$

\section{Health-oriented systems for rearing animals}

Intensive livestock production is dependent on the routine use of antimicrobials to prevent the diseases that are inevitable when animals are kept in poor conditions. However, this leads to the emergence of antimicrobial resistance in animals which can then be transferred to people so undermining the efficacy of the antimicrobials that are so important in human medicine. If we want to save our antimicrobials and minimise the risk of future pandemics, we need to move to 'health-oriented systems' for the rearing of animals, systems in which good health is inherent in the farming method rather than being propped up by routine use of antimicrobials.

What would these health-oriented systems look like? They would avoid overcrowding as high densities are a risk factor for the spread and development of infectious disease; such densities can allow rapid selection and amplification of pathogens. ${ }^{52}$ They would minimise stress as this undermines animals' immunity making them susceptible to disease. ${ }^{53}$ They would ensure that animals can engage in their natural behaviours as inability to so is stressful. ${ }^{54}$

There would be no early weaning of pigs as this involves several stressors including premature separation from the sow, mixing with unfamiliar pigs and having to get accustomed to a new diet and new housing. ${ }^{55}$ Health-oriented systems would avoid excessive herd and flock sizes as this can accelerate the transmission of pathogens. ${ }^{56}$ They would avoid mixing with unfamiliar animals as this is stressful and can result in the introduction of disease. ${ }^{57}$ They would ensure good air quality such as low levels of dust, ammonia and carbon dioxide as poor air quality can lead to respiratory disease. ${ }^{58}$ They would, moreover, avoid the use of animals genetically selected for very fast growth rates and high yields as these animals are vulnerable to immunological and metabolic problems. ${ }^{59}$

\section{Doughnut economics}

The Covid-19 crisis indicates that we need to rethink our relationship with the natural world and treat it, and the creatures within it, with much more respect. To accomplish this we need to adopt a fresh approach to economics. Our current economic model focuses on gross domestic product which is a crude way of measuring progress. We need to move to a more nuanced model such as Doughnut Economics. ${ }^{60}$ The outer ring sets out the planetary boundaries such as GHG emissions and biodiversity loss which we must not overshoot. The inner circle contains societal objectives such as social justice, good health and nutritious food where we must not fall short.

This approach can help us assess whether proposed economic activities are going to harm the planet and whether they are going to contribute to, or detract from, social objectives. It is really an excellent model for charting our post-Covid future. I have got just one concern. Within its 21 planetary boundaries and societal objectives, it finds no room for animal well-being. I propose adding a $22^{\text {nd }}$ element to the doughnut: good animal welfare.

\footnotetext{
GRINSVEN, H, SUTTON, MA, OENEMA, O. Food choices, health and environment: Effects of cutting Europe's meat and dairy intake. Global Environmental Change, 26 (2014) 196-205. http://www.sciencedirect.com/science/article/pii/S0959378014000338 ${ }^{51}$ Ibid

52 OTTE, J, ROLAND-HOLST, D, PFEIFFER, D, SOARES-MAGALHAES, R, RUSHTON, J, GRAHAM, J, SILBERGELD, E. Industrial Livestock Production and Global Health Risks. Food and Agriculture Organization of the United Nations, Pro-Poor Livestock Policy Initiative Research Report (2007).

${ }^{53}$ EMA (European Medicines Agency) and EFSA (European Food Safety Authority), EMA and EFSA Joint Scientific Opinion on measures to reduce the need to use antimicrobial agents in animal husbandry in the European Union, and the resulting impacts on food safety (RONAFA) (2017). EFSA Journal, 15/1 (2017) 4666

${ }^{54}$ Ibid

${ }^{55}$ CALLAWAY, TR, MORROW, JL, EDRINGTON, TS, GENOVESE, KJ, DOWD, S, CARROLL, J, DAILEY, JW, HARVEY, RB, POOLE, TL, ANDERSON, RC, NISBET, TJ. Social Stress Increases Fecal Shedding of Salmonella Typhimurium by Early Weaned Piglets. Curr. Issues Intestinal Microbiol. 7 (2006) 65-72.

56 O'NEILL, J. The Review on Antimicrobial Resistance. Tackling drug-resistant infections globally: final report and recommendations (2016) http://amr-review.org/sites/default/files/160518_Final\%20paper_with\%20cover.pdf

${ }^{57}$ European Commission, Guidelines for the prudent use of antimicrobials in veterinary medicine (Brussels 2015)

${ }^{58}$ Ibid

${ }^{59}$ RAUW, WM, KANIS, E, NOORDHUIZEN-STASSEN, EN, GROMMERS, FJ. Undesirable side effects of selection for high production efficiency in farm animals: a review. Livestock Production Science, 56, 1/1 (1998) 15-33

${ }^{60} \mathrm{https}: / /$ www.kateraworth.com/ Accessed 24 August 2020
} 


\section{Conclusions}

The Farm to Fork Strategy could lead to much better animal welfare and a much improved environment. However, it can only do so if the Commission and the Member States recognise that it is not enough to place some greening around the edges of the status quo. They need to recognise that we need to dismantle the industrial model of agriculture and replace it with health-oriented systems for rearing animals and regenerative agriculture such as agroecology. Moreover, this must be accompanied by a reduction in the consumption of meat and dairy. To improve animal welfare:

- The EU must phase out by law the use of farrowing crates and repeal the derogation that allows sow stalls to be used for the first 28 days of the pregnancy;

- The European Commission must now take urgent steps to secure enforcement of the ban on the routine tail docking of pigs;

- Several Member States have prohibited the use of enriched cages for laying hens. The EU as a whole must now prohibit enriched cages;

- The EU should urgently prohibit the live export of animals from the EU;

- The EU should urgently phase out the use of the electrical waterbath for the stunning of poultry and the use of high concentrations of carbon dioxide for the stunning of pigs.

To enhance the environment and sustainability, we need to move to new ways of farming. First, we need to redefine the role of livestock. Animals are only efficient when they are converting materials we cannot consume into food that we can eat. Second, we need to move to regenerative forms of agriculture. These can minimise the use of pesticides and fertilisers, while at the same time in some cases enhancing productivity and they achieve this by supporting - and harnessing - natural processes. Third, we need to restore the link between animals and the land, for example through rotational integrated crop-livestock systems.

\section{Bibliography}

- BAILEY, R., FROGGATT, A., AND WELLESLEY, L. Livestock - Climate Change's Forgotten Sector (London 2014). Chatham House. Available at: https://www.chathamhouse.org/publication/livestock-climate-change-forgotten-sector-globalpublic-opinion-meat-and-dairy. [Accessed: 2 November 2020]

- BAJŽELJ, B., RICHARDS, K., ALlWOOD, J., SMITH, P., DENNIS, J., CURMI, E., AND GILLIGAN, C. Importance of food-demand management for climate mitigation. Nature Climate Change, 4 (2014) 924-9

- BAXTER, E., LAWRENCE, A., AND EDWARDS, S. Alternative farrowing accommodation: welfare and economic aspects of existing farrowing and lactation systems for pigs. Animal, 6.01 (2012) 96-117. doi: 10.1017/S1751731111001224

- BERNERS-LEE M., WATSON, R., KENNELlY, C., AND HEWITT, C. Current global food production is sufficient to meet human nutritional needs in 2050 provided there is radical societal adaptation. Elementa Science of the Anthopocene, 6 (2018) 52. DOI: https://doi.org/10.1525/elementa.310.

- BRZOZOWSKI, L., AND MAZOUREK, M. A Sustainable Agricultural Future Relies on the Transition to Organic Agroecological Pest Management. Sustainability. 10 (2018) 2023. Available at: https://www.mdpi.com/2071-1050/10/6/2023. [Accessed: 2 November 2020].

- BUCKWELL, A., NADEU, E. What is the Safe Operating Space for EU Livestock? The RISE Foundation (Brussels 2018)

- CAllawAy, T., MORROW, J., EDRINGTON, T., GENOVESE, K., DOWD, S., CARROLL, J., DAILEY, J., HARVEY, R., POOLE, T., ANDERSON, R., AND NISBET, T. Social Stress Increases Faecal Shedding of Salmonella Typhimurium by Early Weaned Piglets. Current Issues in Intestinal Microbiology, 7 (2006) 65-72.

- COUNCIL DIRECTIVE 2007/43/EC laying down minimum rules for the protection of chickens kept for meat production. (2007). Official Journal of the European Union. L182: 19-28.

- COUNCIL DIRECTIVE 2008/120/EC laying down minimum rules for the protection of pigs requires sows and gilts to be kept in groups during a period starting from four weeks after insemination. (2009). Official Journal of the European Union. L.47: 5-17. 
- COUNCIL DIRECTIVE 98/58/EC concerning the protection of animals kept for farming purposes. (1998). L221: 22-27.

- DAMANIA, R., DESBUREAUX, S., RODELlA, A., RUSS, J., AND ZAVERI, E. Quality Unknown: The Invisible Water Crisis. Washington DC: World Bank (2019) Available at: https://openknowledge.worldbank.org/handle/10986/32245. [Accessed: 2 November 2020].

- EDMONDSON, J., DAVIES, Z., AND GASTON, K. Urban cultivation in allotments maintains soil qualities adversely affected by conventional agriculture. Journal of Applied Ecology, 51 (2014) 880 889.

- EFSA PANEL ON ANIMAL HEALTH AND ANIMAL WELFARE. Welfare aspects of the main systems of stunning and killing the main commercial species of animals. The EFSA Journal, 45 (2004) 1-29.

- EFSA PANEL ON ANIMAL HEALTH AND WELFARE. Scientific Opinion on the welfare of pigs at slaughter. The EFSA Journal. 18/6 (2020) 6148.

- EUROPEAN COMMISSION Presentation "Development of plant proteins in the European Union" (9 October 2018).

- EUROPEAN COMMISSION JOINT RESEARCH CENTRE. (2018). Atlas of Desertification (2018). Available at: https://wad.jrc.ec.europa.eu/. [Accessed: 2 November 2020].

- EUROPEAN COMMISSION. (2020). Overview report: welfare of animals transported by sea. DG(SANTE) 2019-6835.

- EUROPEAN COMMISSION. (2020). Overview report: welfare of animals exported by road. DG(SANTE) 2019-6834.

- EUROPEAN COMMISSION. Commission Staff Working Document. Genetically modified commodities in the EU. (2016). Available at: https://ec.europa.eu/transparency/regdoc/rep/10102/2016/EN/10102-2016-61-EN-F1-1.PDF.

[Accessed 2 November 2020].

- EUROPEAN COMMISSION. EU Market Situation for Eggs: Committee for the Common Organisation of the Agricultural Markets. (2020). Available at: https://ec.europa.eu/info/foodfarming-fisheries/animals-and-animal-products/animal-products/eggs_en. [Accessed: 2 November 2020].

- EUROPEAN COMMISSION. EU market: cereals supply \& demand. (2020). Available at: http://ec.europa.eu/agriculture/cereals/balance-sheets/cereals/overview_en.pdf. [Accessed: 2 November 2020].

- EUROPEAN COMMISSION. Guidelines for the prudent use of antimicrobials in veterinary medicine. 2015. Official Journal of the European Union. C299: 7-26.

- EUROPEAN COMMISSION. Outcome of Commission actions to reduce tail biting and prevent routine tail docking of pigs. (2019). Available at: https://ec.europa.eu/info/food-farmingfisheries/key-policies/committees-and-advisory-councils/civil-dialogue-groups/animalproducts_en\#y2019. [Accessed: 2 November 2020].

- EUROPEAN COMMISSION. The European Green Deal. (2019). COM (2019) 640 final. Available at: $\quad$ https://ec.europa.eu/info/sites/info/files/european-green-deal-communication_en.pdf. [Accessed: 2 November 2020].

- EUROPEAN FOOD SAFETY AUTHORITY. Scientific Opinion of the Panel on Animal Health and Welfare on a request from Commission on the risks associated with tail biting in pigs and possible means to reduce the need for tail docking considering the different housing and husbandry systems. The EFSA Journal, 611 (2007) 1-13.

- EUROPEAN FOOD SAFETY AUTHORITY: PANEL ON ANIMAL AND WELFARE. Scientific opinion on welfare aspects of various systems for keeping laying hens. The EFSA Journal, 197 (2005) 1-23.

- EUROPEAN MEDICINES AGENCY AND EUROPEAN FOOD SAFETY AUTHORITY. EMA and EFSA Joint Scientific Opinion on measures to reduce the need to use antimicrobial

- agents in animal husbandry in the European Union, and the resulting impacts on food safety

- (RONAFA). EFSA Journal. 15/1 (2017) 4666.

- EUROPEAN PARLIAMENT resolution of 14 February 2019 on the implementation of Council Regulation (EC) No 1/2005 on the protection of animals during transport within and outside the EU (2018/2110(INI)).

- FOOD AND AGRICULTURE ORGANISATION OF THE UNITED NATIONS. Agroecology to reverse soil degradation and achieve food security. (2015). Rome: FAO. Available at: 
http://www.fao.org/3/a-i4803e.pdf. [Accessed: 2 November 2020].

- FRIEL, S., DANGOUR, A., GARNETT, T., LOCK, K., CHALABI, Z., ROBERTS, I., BUTLER, A., BUTLER, C., WAAGE, J., MCMICHAEL, A., AND HAINES, A. Health and Climate Change 4: Public health benefits of strategies to reduce greenhouse-gas emissions: food and agriculture. The Lancet, 274 (2009) 2016-2025.

- http://www.siwi.org/documents/Resources/Policy_Briefs/PB_From_Filed_to_Fork_2008.pdf. [Accessed: 2 November 2020].

- LELIEVELD J., EVANS, J., GIANNADAKI, D., AND POZZER, A. The contribution of outdoor air pollution sources to premature mortality on a global scale. Nature, 525 (2015) 367-71.

- LETTER dated 16 December 2013 from Commissioner Borg (reference A (2013) 03696985) in response to an open letter dated 23 October 2013 presented by petitioners from the Supporting Better Dairy campaign.

- LUNDQViST, J., DE FRAITURE, C., AND MOLDEN, D. Saving Water: From Field to Fork Curbing Losses and Wastage in the Food Chain. (2018). SIWI Policy Brief.

- MEKONNEN, M., AND HOEKSTRA, A. A global assessment of the water footprint of farm animal products. Ecosystems, 15 (2012) 401-415. DOI: 10.1007/s10021-011-9517-8

- NALON, E., STEVENSON, P. Protection of Dairy Cattle in the EU: State of play and directions for policymaking from a legal and animal advocacy perspective. Animals, 9 (2019) 1066. doi:10.3390/ani9121066

- NELLEMANN, C., MACDEVETTE, M., MANDERS, T., EICKHOUT, B., SVIHUS, B., PRINS, A., AND KALTENBORN, B. The environmental food crisis - The environment's role in averting future food crises. A UNEP rapid response assessment. (2009). United Nations Environment Programme, GRID-Arendal. Available at: https://www.gwp.org/globalassets/global/toolbox/references/the-environmental-crisis.-theenvironments-role-in-averting-future-food-crises-unep-2009.pdf. [Accessed: 2 November 2020]

- O'NEILL, J. The Review on Antimicrobial Resistance. Tackling drug-resistant infections globally: final report and recommendations. (2016). Available at: http:/amrreview.org/sites/default/files/160518_Final\%20paper_with\%20cover.pdf. [Accessed: 2 November 2020]

- OTTE, J., ROLAND-HOLST, D., PFEIFFER, D., SOARES-MAGALHAES, R., RUSHTON, J., GRAHAM, J., AND SILBERGELD, E. Industrial Livestock Production and Global Health Risks. Rome: Food and Agriculture Organization of the United Nations (2007)

- POULTRY WORLD. Diversity, not uniformity in waterbath stunning. (2019). Available at: https://www.poultryworld.net/Health/Articles/2019/1/Diversity-not-uniformity-in-waterbathstunning-378064E/. [Accessed 2 November 2020].

- POUX, X., AUBERT, P. An agroecological Europe in 2050: multifunctional agriculture for healthy eating. (2018). Paris: Iddri-AScA. Available at: https://www.iddri.org/sites/default/files/PDF/Publications/Catalogue\%20Iddri/Etude/201809ST0918EN-tyfa.pdf. [Accessed: 2 November 2020].

- RAJ, A., GREGORY, N. Welfare implications of the gas stunning of pigs: 2. Stress of induction of anaesthesia. Animal Welfare, 5 (1996) 71-78.

- RAUW, W., KANIS, E., NOORDHUIZEN-STASSEN, E., AND GROMMERS, F. Undesirable side effects of selection for high production efficiency in farm animals: a review. Livestock Production Science. 56/1 (1998) 15-33.

- RAWORTH, K. Exploring doughnut economics (2017). Available at: https://www.kateraworth.com/. [Accessed: 2 November 2020].

- RUSSELL, W, AND BURCH, R. The Principles of Humane Experimental Technique (London 1959)

- SCHADER, C., MULlER, A., SCIALABBA, N., HECHT, J., ISENSEE, A., ERB, K., SMITH, P., HARINDER, P., KLOCK, P., LEIBER, F., SCHWEGLER, P., STOLZE, M., AND NIGGLE, U. Impacts of feeding less food-competing feedstuffs to livestock on global food system sustainability. Journal of the Royal Society Interface. 12 (2015) 20150891. Available at: http://dx.doi.org/10.1098/rsif.2015.0891. [Accessed 2 November 2020].

- STOLBA, A., AND WOODGUSH, D. The behaviour of pigs in a semi-natural environment. Animal Protection, 48 (1989) 419-425.

- SUTtON, M., HOWARD, C., ERISMAN, J., BILlEN, G., BLEEKER, A., GRENNFELT, P., VAN GRINSVEN, H., AND GRIZZETTI, B. The European Nitrogen Assessment (Cambridge 
2011)

- VANHAM, D., MEKKONEN, M., AND HOEKSTRA, A. The water footprint of the EU for different diets. Ecological Indicators, 32 (2013) 1-8. Available at: http://waterfootprint.org/media/downloads/Vanham-et-al-2013_2.pdf. [Accessed: 2 November 2020].

- WEBER, R., KEIL, N., FEHR, M., AND HORAT, R. Piglet mortality on farms using farrowing systems with or without crates (South Mimms). Animal Welfare, 16 (2007) 277-279.

- WESTHOEK, H., LESSCHEN, J., ROOD, T., WAGNER, S., DE MARCO, A., MURPHYBOKERN, D., LEIP, A., VAN GRINSVEN, H., SUTTON, M., AND OENEMA, O. Food choices, health and environment: Effects of cutting Europe's meat and dairy intake. Global Environmental Change, 26 (2014) 196-205. Available at: http://www.sciencedirect.com/science/article/pii/S0959378014000338. [Accessed: 2 November 2020].

- WORLD HEALTH ORGANIZATION AND SECRETARIAT OF THE CONVENTION ON BIOLOGICAL DIVERSITY. Connecting global priorities: biodiversity and human health. Switzerland: World Health Organisation (2015) 